\title{
CZY PRZYJAŹŃ ETYCZNA NIE JEST PRZYJAŹNIĄ POZORNĄ? - ROZWAŻANIA WOKÓŁ DRUGIEGO ROZDZIAŁU SIÓDMEJ KSIĘGI ETYKI EUDEMEJSKIEJ
}

Słowa kluczowe: przyjaźń etyczna, prawdziwy przyjaciel, szlachetny człowiek, dobry człowiek

Keywords: ethical friendship, true friend, noble man, good man

\section{Wstęp}

W drugim rozdziale siódmej księgi Etyki eudemejskiej (EE) pojawia się wypowiedź, która wprawia w zakłopotanie w kontekście rozważań na temat przyjaźni etycznej, czyli przyjaźni z powodu cnoty/doskonałości $\left(\delta \iota^{\prime} a ̊ \rho \in T \eta ́ v\right)^{1}$. Arystoteles zdaje się bowiem sugerować, że jeśli w przyjaźni etycznej jakiś przykry akcydens, na przykład smród wydzielany przez

* Maciej Smolak - dr, pracuje w Zakładzie Filozofii Kultury w Instytucie Filozofii UJ, obecnie zajmuje się teorią przyjaźni i teorią przyjemności u Arystotelesa, a także dydaktyką filozofii i interaktywnymi metodami nauczania w filozofii. E-mail: m.smolak@ iphils.uj.edu.pl.

Address for correspondence: E-mail:m.smolak@iphils.uj.edu.pl.

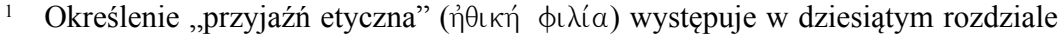
siódmej księgi EE w kontekście rozważań na temat przyjaźni obywatelskiej. Wprawdzie w 1242b32-33 Arystoteles używa predykatu ,etyczna” na określenie jednego z typów przyjaźni utylitarnej, ale w 1243a31-36 wyraźnie daje już do zrozumienia, że przyjaźń etyczna jest przyjaźnią z powodu cnoty/doskonałości, a tworzący ją przyjaciele są przy-

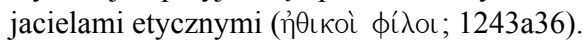


przyjaciela, zaczyna przeszkadzać do tego stopnia, że przebywanie w jego towarzystwie przestaje sprawiać radość, to przyjaciel zostaje opuszczony przez swojego przyjaciela $(E E, 1237 \mathrm{~b} 5-7)$. Ale cóż to za przyjaciel etyczny, można by zapytać, który opuszcza swojego przyjaciela w biedzie? I cóż to za przyjaźń etyczna, która nie wytrzymuje próby czasu? Pytania tym bardziej skłaniają do namysłu, gdyż Arystoteles podziela powszechnie głoszoną opinię, że czas pokazuje, kto jest przyjacielem i to bardziej w niepowodzeniu, niż wtedy, gdy się wiedzie (1238a14-16). Akceptuje ponadto powiedzenie, że „chcąc poznać przyjaciela, trzeba zjeść z nim beczkę soli” (1238a2-3).

Artykuł składa się z trzech punktów. W pierwszym prezentuję charakterystykę prawdziwego przyjaciela. W drugim, wyróżniam i opisuję dwa typy przyjaźni etycznej. W trzecim, przedstawiam trzy interpretacje, które łagodzą niepożądany wydźwięk rzeczonej wypowiedzi.

\section{Charakterystyka prawdziwego przyjaciela}

Arystoteles zauważa, że prawdziwy przyjaciel to przyjaciel prymarny

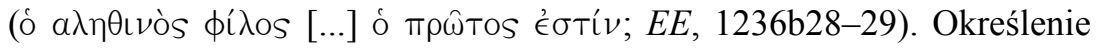
„prymarny” wskazuje, że chodzi o przyjaciela tworzącego przyjaźń prymarną, czyli przyjaźń, której stronami relacji są ludzie dobrzy $(\dot{\eta} \pi \rho \omega ́-$

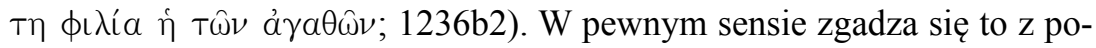
wszechnie akceptowaną opinią ( $€ \nu \delta o \xi o \nu$ ), ponieważ w pierwszym rozdziale siódmej księgi EE Arystoteles dwukrotnie przytacza poglądy tych, którzy uważają, że przyjacielem może być jedynie człowiek dobry². W pewnym sensie, ponieważ Arystoteles traktuje opinie ( $\left.{ }^{\prime \prime} \nu \delta o \xi \alpha\right)$ jako wyjściowy materiał, od którego zaczyna budowanie teorii, ale który w toku prowadzonego badania poddaje zazwyczaj reinterpretacji ${ }^{3}$. Jest tak również $\mathrm{w}$ tym

2 Arystoteles stwierdza: „wydaje się, że ten sam mężczyzna jest nie tylko dobry, lecz również jest przyjacielem” (EE, 1234b24-25); ,,jednym wydaje się, że ci, którzy są podli, nie mogą być przyjaciółmi, lecz jedynie ci, którzy są dobrzy” (1235a32-33).

3 Jest to efekt stosowanej przez Arystotelesa metody, którą w Fizyce [Fiz], 184a16 określa „naturalną drogą badania”. Metoda służy poznaniu tego, co znane z natu-

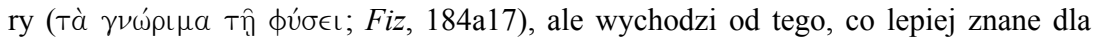

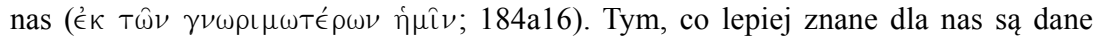
( ̀̀ $\phi a \iota \nu o ́ \mu \in \nu a)$, na które składają się fakty empiryczne i powszechnie akceptowane opinie lub opinie ludzi wykształconych, zwłaszcza wybitnych i szanowanych (Topiki, 
przypadku, ponieważ ci, którzy tworzą prymarną przyjaźń, są całkowicie

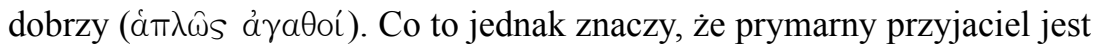
całkowicie dobry?

Gdy Arystoteles przeprowadza charakterystykę człowieka całkowicie dobrego z punktu widzenia prymarnej przyjaźni, podkreśla, że jest on wart

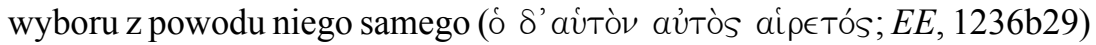

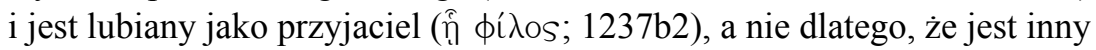

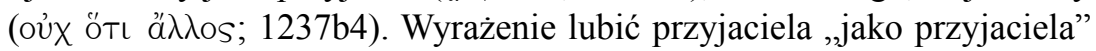
podkreśla, że naszą uwagę przykuwa sama osoba przyjaciela, czyli jej istotne cechy, natomiast wyrażenie lubić przyjaciela „dlatego, że jest inny” nie tyle sugeruje, że lubimy kogoś, ponieważ jest kimś innym niż się nam wydaje, lecz głównie to, że skupiamy się na jego cechach akcydentalnych. Konstytucja prymarnego przyjaciela sprawia, że jest on obiektem troski

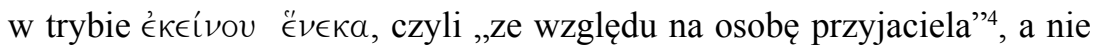
jedynie z ukrytych powodów, które świadczyłyby wyłącznie o instrumentalnym traktowaniu przyjaciela. Przyjaźń zakłada wzajemność, więc prymarny przyjaciel jest nie tylko obiektem troski w trybie ,ze względu na osobę przyjaciela", lecz jest równocześnie zdolny do jej przejawiania. Czyli troska w trybie ,ze względu na osobę przyjaciela” jest możliwa nie tylko dlatego, że obiekt troski jest odpowiednio ukonstytuowany, lecz również dlatego, że taki wymóg spełnia troszczący się ${ }^{5}$.

100b21-23). Ponieważ takie opinie są często ze sobą niezgodne, więc to generuje pojawienie się trudności do rozwiązania (ảmopía). Wystąpienie trudności i jej rozpoznanie przez badacza jest jednak czymś korzystnym, ponieważ dopiero wtedy badacz staje się w pełni świadomy problemu, który zamierza rozwiązać (Metafizyka [Met], 995a24995b2). Na temat metody badawczej Arystotelesa, por. np.: Irwin, 1990; Broadie, 1991, s. 17-24; Bostock, 2000, s. 214-235; Pakaluk, 2005, s. 25-37.

4 Arystoteles wyraża to w następujący sposób: ,ten, dla kogo ktoś chce dobrych rzeczy z powodu niego samego, musi być również wart wyboru z powodu niego same-

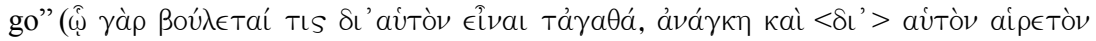

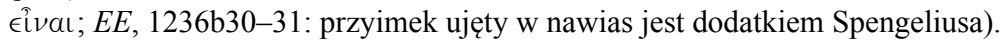

5 Zwraca na to uwagę na przykład Stern-Gillet (1995, s. 64-77), podkreślając, że

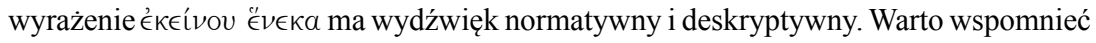
przy tej okazji, że ktoś może spełniać wymogi prymarnego przyjaciela i nie być traktowanym jako prymarny przyjaciel. Mówi o tym Arystoteles, gdy wskazuje na możliwość

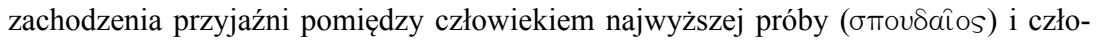
wiekiem podłym lub akratykiem (EE, 1238b3-5). W takim wypadku żadna ze stron nie traktuje swojego przyjaciela jako cel i obiekt bezinteresownej troski. Człowiek podły lub akratyk dlatego, że nie są do tego zdolni - nie są odpowiednio ukonstytuowani i nie 
Na ową konstytucję Arystoteles zdaje się wskazywać, gdy, opracowując typologię przyjaźni w oparciu o powody lubienia, stwierdza, że ,jednego lubimy dlatego, że jest taki oto (T⿳亠丷 Toıó $\delta €)$ " (1236a12). Wyrażenie Tஸ̣ Toıó $\delta € \in$ może sygnalizować, że ktoś jest przyjacielem nie dlatego, że jest dobry pod pewnym względem - na przykład dlatego, że jest mężny lub

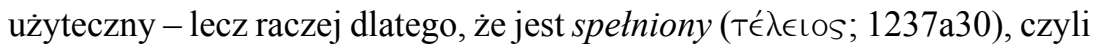
osiągnął cel, którym jest samorozwój (öTı кaì $\tau \in \lambda \in \mathrm{\epsilon} \omega \theta \in ́ \nu \tau \iota ; 1237 \mathrm{a} 29)^{6}$. Potwierdzać to może skrótowa charakterystyka przyjaźni tego typu przyjaciół, ponieważ w stosunku do poprzedzającego ją opisu przyjaźni utylitarnej i hedonicznej pojawia się istotna modyfikacja. O ile w przypadku przyjaź-

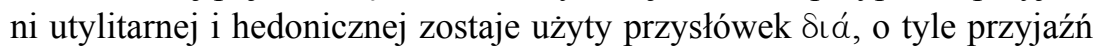
prymarna scharakteryzowana jest za pomocą przysłówka кaтá (1237b1). Wprawdzie w siódmej księdze EE (por. np. 1241a4-5) Arystoteles używa również przysłówka kaтá w kontekście wypowiedzi traktujących o przyjaźni hedonicznej i przyjaźni utylitarnej, ale miejsce to jest szczególne - po ustaleniu powodów lubienia i wyróżnieniu na tej podstawie trzech typów przyjaźni, Arystoteles wykazuje, kto takie przyjaźnie tworzy. Z przedstawionego opisu wynika, że co prawda przyjaźń hedoniczna i przyjaźń utylitarna różnią się między sobą powodem, ale łączy je to, że przyjaciele traktują się instrumentalnie. Przyjaźń etyczną odróżnia natomiast od pozostałych typów nie tylko powód, lecz również sposób wzajemnego traktowania się

spełniają wymogów nałożonych na prymarnego przyjaciela. Człowiek najwyższej próby dlatego, że obiekt troski nie spełnia takiego wymogu. Zatem nawet człowiek najwyższej próby, mimo że jest odpowiednio ukonstytuowany, żeby dążyć do celów swojego przyjaciela jako do niezależnych dóbr, a nie tylko jako do części swojego własnego dobra, nie może troszczyć się o swojego przyjaciela ,ze względu na niego samego”, o ile nie jest on prymarnym przyjacielem. Jak zauważa Vlastos (1973, s. 33, przyp. 100), realizowanie dobrych rzeczy dla przyjaciela w trybie ,ze względu na niego” jest wbudowane w lubienie w jego najlepszej formie, ale pod warunkiem, że to nie wyklucza oceny cnót przyjaciela. Realizowanie dobrych rzeczy dla przyjaciela w trybie ,ze względu na niego” zakłada więc uprzednie rozpoznanie, że przyjaciel jest wart wyboru z powodu niego samego.

6 Przed przystąpieniem do wyróżnienia powodów lubienia Arystoteles zauważa, że dobro orzekamy na wiele sposobów i że o pewnej rzeczy orzekamy, że jest dobra dlatego, że jest taka oto ( jeszcze o innej dlatego, że jest przyjemna $(E E, 1236 a 7-10)$. Wyrażenie Tழ̣ toıó $\delta \delta \in$ może

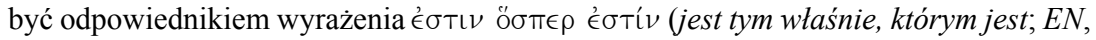
1156a18), przy pomocy którego w EN Arystoteles identyfikuje przyjaciela tworzącego pełną przyjaźń ( $\tau \in \lambda \in i ́ a)$, czyli przyjaźń będącą odpowiednikiem przyjaźni prymarnej. 
przyjaciół etycznych. Sądzę więc, że zmiana przysłówka w tym właśnie miejscu jest zamierzona.

Arystoteles stwierdza, że ,,przyjaźń według cnoty/doskonałości jest

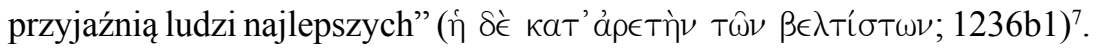
Zmiana przysłówka jest uzasadniona, ponieważ Arystotelesowi zależy nie tylko na tym, żeby osłabić celowościowy wydźwięk powodu lubienia i przenieść punkt ciężkości z celu lubienia na rację lubienia, lecz również na tym, by zwrócić uwagę na ukonstytuowanie przyjaciela w przyjaźni tego

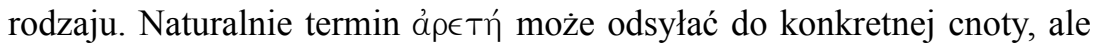
ponieważ Arystoteles ma w tym kontekście na myśli ludzi najlepszych, więc chodzi mu raczej o tych, którzy są nie tyle najlepsi w konkretnej dziedzinie praktycznych działań, lecz o tych, którzy są najlepsi, ponieważ prowadzą

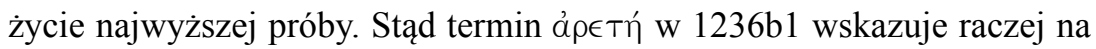
doskonałe ustrukturyzowanie człowieka ${ }^{8}$, które sprawia, że potrafi on zogni-

7 Wywód Arystotelesa z wyróżnionym miejscem ma następującą postać: , [...] jest wiele typów przyjaźni, ponieważ to była jedna z tych rzeczy, o których już mówiliśmy, skoro rozróżniliśmy trojakie orzekanie przyjaźni. Rozróżniliśmy bowiem przyjaźń z powodu cnoty/doskonałości, z powodu tego, co użyteczne i z powodu tego, co przyjemne. Z nich przyjaźń z powodu tego, co użyteczne jest przyjaźnią większości ludzi (ponieważ lubią się z powodu wzajemnej użyteczności i dopóki są użyteczni, jak mówią przysłowia: Glauku, pomocnik jest twoim przyjacielem do momentu, gdy walczy i Ateńczycy nie znają już Megarejczyków), przyjaźń z powodu przyjemności jest przyjaźnią młodych (ponieważ kierują się postrzeżeniem tego, co przyjemne; dlatego przyjaźń młodych łatwo się zmienia; kiedy bowiem zmieniają się cechy charakteru wraz z dojrzewaniem, zmienia się również to, co przyjemne), natomiast przyjaźń według cnoty/doskonałości jest przyjaźnią ludzi najlepszych. Jest zatem jasne, na podstawie tego, co zostało powiedziane, że prymarna przyjaźń, przyjaźń ludzi dobrych, jest odwzajemnionym przyjaznym uczuciem i odwzajemnioną decyzją między nimi” (EE, 1236a30-1236b3). Warto podkreślić, że w wielu przekładach zmiana przysłówka nie jest w ogóle odnotowana przez translatorów. Por. Dirlmeier, (Aristoteles, 1962); Wróblewski, (Arystoteles, 1977). Są jednak również przekłady, które taką zmianę uwzględniają. Por. Rackham, (Aristotle, 1962); Zanata, (Aristotele, 2012).

8 W Kategoriach, 10b5-9 Arystoteles zauważa, że są przypadki, w których określa-

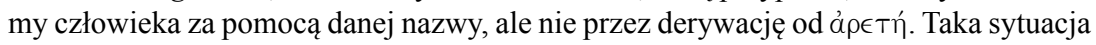

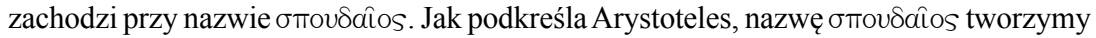

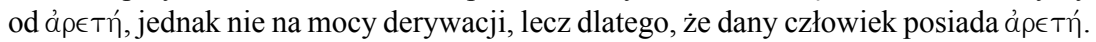

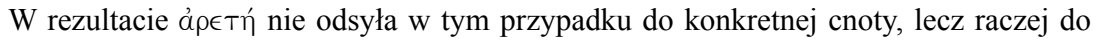
zespołu cnót fundujących całościową strukturę. Dopiero wystąpienie takiej holistycznej

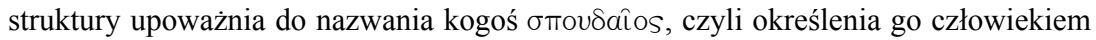

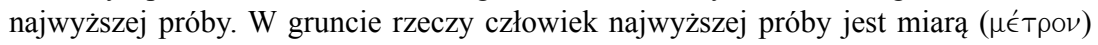


skować swoje myślenie praktyczne, pragnienia oraz decyzje na najwyższym możliwym do osiągnięcia przez człowieka dobru, czyli na eudaimonii, ale właściwie pojętej. W przypadku takiego człowieka dochodzi bowiem do zespolenia doskonale rozwiniętego charakteru i doskonale rozwiniętego rozumu praktycznego, a w konsekwencji do wytworzenia praktycznego centrum decyzyjnego ${ }^{9}$, które świadczy o osiągnięciu przez niego pełnej harmonii duchowej. Potwierdza to między innymi teza o nierozdzielności cnoty etycznej i roztropności oraz ściśle z nią związana teza o nierozdzielności cnót etycznych $(E E, 5.13=E N, 6.13)^{10}$.

Można więc przyjąć, że prymarny przyjaciel to taki, który jest całkowicie dobry ze względu na konstytucję duchową. Ale czy prymarny przyjaciel musi być też całkowicie dobry z punktu widzenia konstytucji cielesnej? Czy prymarny przyjaciel, prócz tego, że jest zdrowy etycznie, musi być również zdrowy fizycznie?

Arystoteles podkreśla, że to, co całkowicie dobre i to, co całkowicie przyjemne jest tym samym i w tym samym czasie $(E E, 1236 \mathrm{~b} 27)$, zatem prawdziwy przyjaciel jest nie tylko całkowicie dobry, lecz również całkowicie przyjemny, a przyjemności dostarcza jego konstytucja duchowa. Przyjaźń prymarna jest dlatego przyjaźnią nie tylko według cnoty/doskonałości, lecz

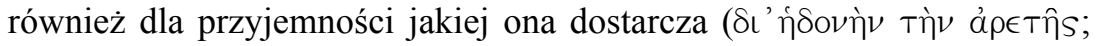
1238a31). Jednak koincydencja całkowitego dobra i całkowitej przyjemności nie jest bezwarunkowa, lecz warunkowa. Arystoteles nie twierdzi, że to, co całkowicie dobre i to, co całkowicie przyjemne jest z a w s z e tym samym i w tym samym czasie, ponieważ dodaje, że taka koincydencja zachodzi, „o ile coś nie stanie na przeszkodzie” (1236b28). Niemniej w przytaczanej już kontrowersyjnej wypowiedzi Arystoteles wskazuje na nieprzewidzianą komplikację, mianowicie przypadłość cielesną w postaci smrodu wydzielanego przez przyjaciela, która może nie tylko utrudnić, ale

w sprawach ludzkich, ponieważ potrafi ocenić, co jest dobre dla człowieka, niezależnie od tego, w jakiej relacji pozostaje do ocenianego dobra.

9 Charakterystykę praktycznego centrum decyzyjnego przeprowadzam w wielu miejscach w Przyjaźń w świetle etyki Arystotelesa (Smolak, 2013).

${ }_{10}$ W EE i $E N$ występują trzy wspólne księgi: $O$ sprawiedliwości $(4 E E=5 E N)$, $O$ cnotach intelektualnych $(5 E E=6 E N)$ i O przyjemności $(6 E E=7 E N)$. Kenny (1978) dowodzi, że wspólne księgi były pierwotnie częściami składowymi $E E$ i ten pogląd jest obecnie akceptowany. W dalszej części artykułu, gdy odnoszę się do treści zawartych w księgach wspólnych, posługuję się paginacją występującą w EN. 
wręcz uniemożliwić czerpanie radości z jego konstytucji duchowej oraz przebywanie w jego towarzystwie. Tymczasem, jeśli przyjaciel nie będzie sprawiał radości jako dobry (1237b4-5) lub jeśli przyjaźni nie będzie towarzyszyć przyjemność pochodząca z wzajemnej znajomości (1237a31), to nie ma prymarnej przyjaźni. Sugerowałoby to, że nawet jeśli przyjaciel jest całkowicie dobry pod względem duchowym, to może się zdarzyć, że nie jest on całkowicie dobry pod względem cielesnym i przyjemność, jakiej dostarcza jego doskonałość duchowa, może być wyparta przez przykrość, jakiej dostarcza chorobowy stan jego ciała. I o takiej sytuacji Arystoteles zdaje się mówić w kłopotliwej wypowiedzi.

\section{Dwa typy przyjaźni etycznej}

W trzecim rozdziale ósmej księgi EE Arystoteles odróżnia tego, kto jest dobrym człowiekiem od tego, kto jest człowiekiem szlachetnym ${ }^{11}$. Pierwszego określa używając terminu ảyaӨós, natomiast drugiego terminem

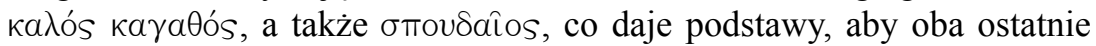
traktować synonimicznie i przez człowieka szlachetnego rozumieć człowieka najwyższej próby. Różnica między człowiekiem dobrym a człowiekiem szlachetnym, ergo najwyższej próby, dotyczy przede wszystkim poziomu rozwoju rozumu w funkcji praktycznej i poziomu rozwoju charakteru.

\subsection{Przyjaźń etyczna ludzi dobrych}

Człowieka nazwany ảya $\theta$ ós, jest dobry, ponieważ posiada cnoty etyczne i ich używa. Dlatego nie ceni ich ze względu na nie same, lecz ze względu na to, że

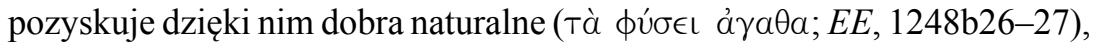
w których zakres wchodzą między innymi zaszczyty i bogactwo, czyli te dobra, które są przedmiotem walki i które są równocześnie uznawane przez większość za najbardziej warte wyboru (1248b27-30). Człowiek dobry ceni zatem dobra, które ceni większość, jednak ze względu na strukturę swojego charakteru dąży do ich posiadania w takiej ilości, na jaką faktycznie zasługuje. Innymi słowy, cnoty etyczne zabezpieczają go przed przekraczaniem miary w pozyskiwaniu dóbr naturalnych i przed używaniem ich w sposób, który byłby dla niego szkodliwy. Nie zmienia to jednak faktu, że człowiek

11 Szczegółową charakterystykę człowieka dobrego i szlachetnego przeprowadzam w Przyjaźn w świetle etyki Arystotelesa (Smolak, 2013, s. 132-138). 
dobry traktuje cnoty etyczne instrumentalnie, ponieważ uważa, że dzięki postępowaniu zgodnym z nimi, zasłuży na to, co uczynił celem swoich dążeń. Dlatego Arystoteles podkreśla, że postępowanie człowieka dobrego jest wprawdzie piękne, ale tylko przypadkowo (1249a15-16) - jest piękne, ponieważ jest zgodne z cnotami etycznymi; jest przypadkowo piękne, ponieważ zachodzi z powodu dóbr naturalnych ${ }^{12}$.

Można więc uznać, że człowiek dobry ma charakter podbudowany tymi czy innymi konkretnymi cnotami etycznymi, które są wytrenowanymi

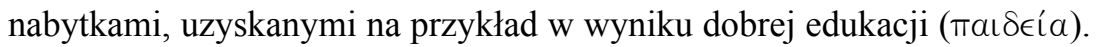
W tym sensie człowiek dobry orientuje się, jak powinien postąpić w określonej sytuacji. Myli się jednak co do treści holistycznego celu życiowego, czyli eudaimonii, ponieważ uważa, że dzięki postępowaniu zgodnemu $\mathrm{z}$ cnotami etycznymi pozyska nagrody - na przykład dostąpi zaszczytów - lub uniknie kar - na przykład nie narazi się na zniewagi. W rezultacie posiadane przez niego cnoty etyczne nie są jeszcze rozwinięte do pełnej postaci między innymi dlatego, że jego wykładnia eudaimonii nie jest na miarę wykładni eudaimonii ujmowanej przez człowieka roztropnego. Tymczasem nie ma w pełni rozwiniętej cnoty etycznej bez roztropności (EN, 1144b17), wprawdzie człowiek dobry postępuje zgodnie z nabytymi cnotami etycznymi i w taki sposób, jakby to określił człowiek roztropny, ale nie w oparciu o własną roztropność, a przynajmniej nie w oparciu o własną roztropność wykształconą do takiej postaci, która gwarantowałaby ujęcie całkowitego celu ludzkiej egzystencji, równoważnego ujęciu koncepcji eudaimonii przez człowieka roztropnego. W istocie zakres działania roztropności nie sprowadza się tylko do deliberowania nad tym, co przyna-

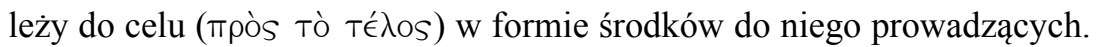
Nie ogranicza się więc tylko do funkcji instrumentalnej, ponieważ jej rolą jest również deliberowanie i uchwytywanie tego, co przynależy do celu

12 W trzynastym rozdziale szóstej księgi EN Arystoteles wyróżnia cnotę naturalną

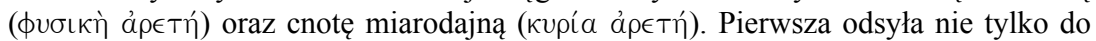
wrodzonej predyspozycji charakterologicznej, lecz również do cnoty etycznej w formie wytrenowanego nabytku, druga natomiast odsyła do cnoty etycznej w pełnym tego sło-

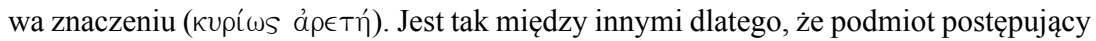
zgodnie z nią, czyni tak przy użyciu własnej roztropności. Gdy Arystoteles twierdzi zatem, że postępowanie człowieka dobrego jest przypadkowo piękne, nie chodzi mu o to, że realizuje się ono z wrodzonej skłonności, lecz o to, że u jego podstawy stoi wykształcona cnota etyczna, niemająca jednak jeszcze statusu cnoty miarodajnej. Charakterystykę cnoty naturalnej i cnoty miarodajnej przeprowadzam w Przyjaźn w świetle etyki Arystotelesa (Smolak, s. 123-131). 
w formie jego konstytutywnych składników, a także deliberowanie i uchwytywanie samego celu, pojmowanego jako właściwy obiekt etycznego dążenia. W konsekwencji dopiero ten, kto jest faktycznie roztropny, potrafi sformułować adekwatną odpowiedź na pytanie „,czym jest eudaimonia i co ją konstytuuje?"13. Dobry człowiek tego jednak nie potrafi, skoro układa swoje życie według koncepcji eudaimonii, w myśl której właściwym obiektem ludzkiego dążenia są dobra naturalne. Można więc przyjąć, że w jego przypadku nie jest spełniona teza o nierozdzielności cnoty etycznej i roztropności, mimo to określenie takiego człowieka terminem áyaӨós nie jest bezpodstawne, ponieważ trafnie rozpoznaje, co jest złe i haniebne oraz postępuje zgodnie z posiadanymi cnotami etycznymi. Nie zasługuje jednak na miano człowieka najwyższej próby, ponieważ jego decyzje i czyny wyznacza w głównej mierze obawa przed karą lub chęć pozyskania nagrody.

Ale są również powody, aby przyjąć, że w przypadku człowieka dobrego nie jest spełniona teza o nierozdzielności cnót etycznych ${ }^{14}$. Ary-

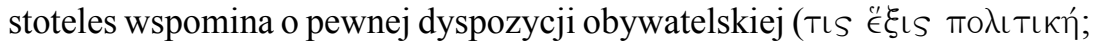
EE, 1248b37-38), którą mają Lacedemończycy. Ponieważ uwaga pojawia się w kontekście charakterystyki człowieka dobrego, więc wydaje się, że Arystoteles jest skłonny zaliczyć tych, którzy taką dyspozycję posiadają, do kategorii ludzi dobrych. Wiele wskazuje, że Arystotelesowi ma w tym

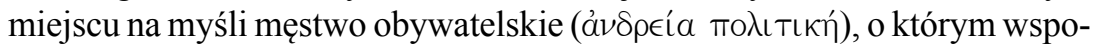
mina między innymi w pierwszym rozdziale trzeciej księgi EE. Wprawdzie męstwa obywatelskiego nie uważa za cnotę męstwa w pełnym tego słowa znaczeniu, ale z pięciu wymienionych form męstwa, określanych tak na podstawie podobieństwa do męstwa w pełnym tego słowa znaczeniu, jest ono do niego najbardziej podobne. Wynika to między innymi z faktu, że ten, kto postępuje zgodnie $\mathrm{z}$ męstwem obywatelskim, naraża się na niebezpieczeństwa, a nawet na śmierć, wywiązuje się z nałożonych obowiązków żołnierskich i trwa niezłomnie na swoim posterunku. Czyni to jednak z niewłaściwego powodu, kieruje się bowiem poczuciem wstydu ( $\delta \iota^{\prime}$ ai $\left.\delta \hat{\omega}\right)$. Nie traktuje więc cnoty męstwa jako dobra wartego wyboru dla niego

13 Zwolennikiem interpretacji, która sprowadza rolę roztropności jedynie do obmyślenia środków w sposób prudencyjny jest na przykład Fortenbaugh (1991, s. 105). Zwolennikami interpretacji, która rozszerza zakres działania roztropności na ujęcie holistycznego celu życiowego są na przykład Gauthier i Jolif, (Aristote, 1959, t. II, cz. 2, s. 563-578).

14 Na temat zawisłości nierozdzielności cnót etycznych od nierozdzielności cnoty etycznej i roztropności por. np. Gauthier i Jolif, (Aristote, 1959, t. II, p. 2, s. 558-559). 
samego, lecz jako środek służący do uniknięcia hańby lub dostąpienia zaszczytów. Dlatego Lacedemończycy słusznie uważają, że powinni posiadać cnotę męstwa, lecz mylą się, że powinni ją posiadać ze względu na dobra naturalne (1248b39-40).

W Polityce [Pol] Arystoteles idzie jednak dalej w krytyce Lacedemończyków, ponieważ deprecjonuje ich porządek praw i system wychowania. Podkreśla, że jest on zogniskowany na kształtowaniu tylko części

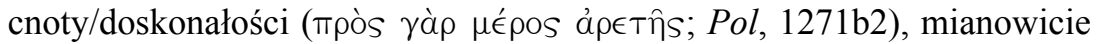

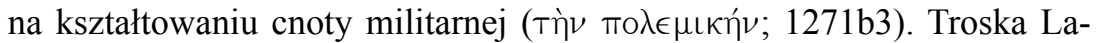
cedemończyków o młodych chłopców sprowadza się do zaprawiania ich w trudach i wykształcania w nich cnoty żołnierskiej, gwarantującej zachowanie męstwa na polu walki. Naturalnie taka cnota jest korzystna dla prowadzenia podbojów i odnoszenia zwycięstw, ale poza trybem wojskowego życia nie znajduje lub nie musi znajdować zastosowania. Dlatego Lacedemończycy potrafią zachować się na polu walki, lecz ze względu na jednostronność ich wychowania nie mają rozeznania, jak postępować w czasie pokoju. Brakuje im bowiem cnót etycznych, które regulowałyby ich zachowanie w pozamilitarnej sferze życia. Oznacza to, że w ich przypadku nie jest spełniona teza o nierozdzielności cnót etycznych.

Na podstawie przeprowadzonej charakterystyki Lacedemończyków

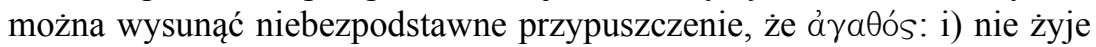
jeszcze według koncepcji eudaimonii równoważnej koncepcji eudaimonii ujmowanej przez człowieka roztropnego, czego wyrazem jest między innymi fakt, że w jego przypadku nie jest spełniona teza o nierozdzielności cnoty etycznej i roztropności; ii) nie ma jeszcze w pełni dobrego charakteru, czego wyrazem jest między innymi fakt, że w jego przypadku nie jest spełniona lub nie musi być spełniona teza o nierozdzielności cnót etycznych.

Gdy więc Arystoteles, opracowując typologię przyjaźni w oparciu o powody lubienia, stwierdza, że ,jednego lubimy dlatego, że jest taki

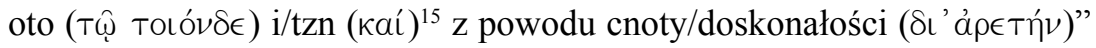

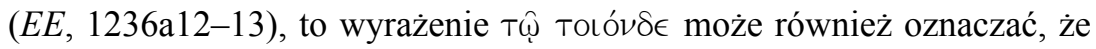
ktoś jest przyjacielem, ponieważ jest pewnej określonej jakości, natomiast

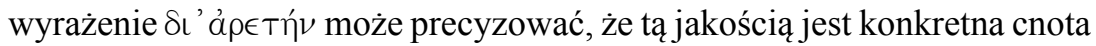
etyczna, czyli konkretna cecha charakteru. W rezultacie Arystoteles mógł

15 Spójnik kaí ma w grece bardzo często znaczenie eksplikatywne. Może więc chodzić w tym miejscu o podkreślenie, że powodem lubienia jest ta czy inna cnota etyczna. Ktoś bowiem może na kogoś zwrócić uwagę z powodu jego cnoty męstwa lub cnoty szczodrości. 
dopuszczać formę przyjaźni etycznej, której powodem jest ta czy inna cnota etyczna i którą tworzą ludzie z typową mieszaniną dobrych i złych cech charakteru (por. Cooper, 1977, s. 624), czyli tacy, którzy nie są jeszcze spetnieni

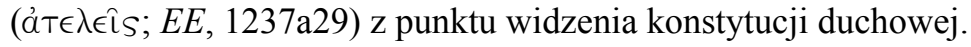

\subsection{Przyjaźń etyczna ludzi szlachetnych}

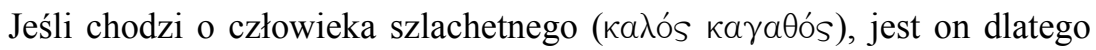

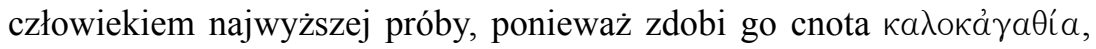
czyli szlachetność ${ }^{16}$, która składa się z poszczególnych cnót etycznych i która jednoczy je oraz przenika, sprawiając równocześnie, że stają się pełnowartościowymi cechami charakteru, czyli zorientowanymi na kreację

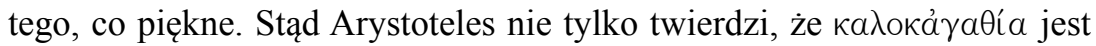

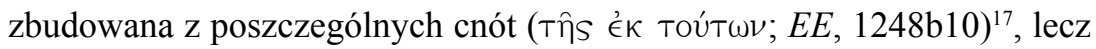

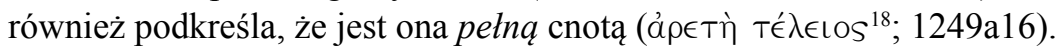

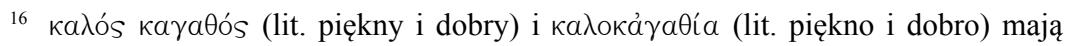

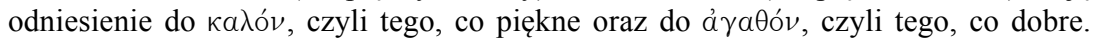
$\mathrm{W}$ istocie oba terminy pierwotnie odsyłały do pełnego ideału człowieka wedle wyobrażeń wczesnogreckiego społeczeństwa i oznaczały perfekcję fizyczną oraz etyczną (por. Jaeger, 2001, s. 48-49). W tym sensie translacja zaproponowana przez Wróblewskiego (Arystoteles, 1977) jest w pełni uzasadniona, ponieważ na gruncie języka polskiego „szlachetny” desygnuje człowieka wewnętrznie zharmonizowanego, postępującego wspaniałomyślnie i wywołującego wrażenie godności oraz piękna.

17 Ponieważ Arystoteles podkreśla, że szlachetność jest zbudowana z cnót, które wcześniej już omówił ( $E E, 1248$ b8-11), więc powstaje problem, o które cnoty chodzi. Można twierdzić, że na szlachetność składają się wszystkie cnoty omówione w EE, a więc konkretne cnoty etyczne i cnoty intelektualne, w szczególności roztropność, czyli cnota rozumu w funkcji praktycznej oraz mądrość, czyli cnota rozumu w funkcji teoretycznej (por. np. Kenny, 1978, s. 206). Można twierdzić, że szlachetność jest zespoleniem roztropności i konkretnych cnót etycznych (taka interpretacja zdaje się możliwa między innymi dlatego, że dopiero wzajemna współpraca cnoty etycznej i roztropności otwiera możliwość osiągania eudaimonii; por. np. Kenny, 1978, s. 193). Można też jednak twierdzić, że na szlachetność składają się konkretne cnoty etyczne (por. np. Engberg-Pedersen, 1983, s. 53). Sądzę, że trzecia interpretacja jest najbardziej obiecująca, ponieważ dopuszcza mówienie o współpracy pomiędzy częścią orektyczną i rozumową duszy, ale w takiej formie, że to, czego domaga się rozum, nie jest odbierane jako nakaz.

18 W szesnastym rozdziale piątej księgi Metafizyki Arystoteles podaje trzy podstawowe znaczenia terminu Té $\lambda \in \iota \mathrm{\nu}$ i podkreśla, że Té $\lambda \in \iota \mathrm{\nu}$ może oznaczać, iż dana rzecz jest: i) kompletna, ponieważ ma wszystkie właściwe dla siebie części; ii) doskonała, ponieważ 
Pomiędzy poszczególnymi cnotami etycznymi i szlachetnością zachodzi wzajemne warunkowanie. Szlachetność odciska na tych pierwszych swoje piętno, wynosząc je w okolice ich własnych maksimów, dzięki czemu podmiot w nie wyposażony, gdy postępuje zgodnie z nimi, czyni tak przede

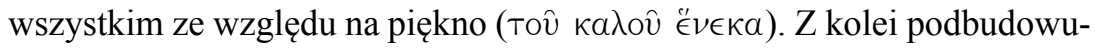
jące szlachetność cnoty etyczne stanowią jej fundament ontyczny, nie ma bowiem szlachetności bez dobrze zorientowanego charakteru, czyli cha-

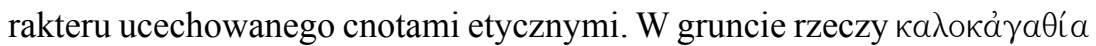
odpowiada za rozmiłowanie podmiotu działającego w pięknie i sprawia, że piękno staje się motywem jego postępowania. Stąd człowiek szlachetny nie tyle urzeczywistnia działania zgodne z cnotami etycznymi w trybie imperatywnym, czyli pod wpływem nakazów rozumu, ile czyni to z głębi samego siebie, ze skłonnością oraz chętnie, ponieważ w jego przypadku doszło do wytworzenia harmonii pomiędzy rozumową i orektyczną częścią duszy ${ }^{19}$. Przy czym owa harmonia nie jest chwilowa, lecz trwała, ponieważ konkretne działania i urzeczywistniane przez człowieka szlachetnego konkretne cele tworzą spójną całość rozpatrywaną z perspektywy obranego i realizowanego przez niego planu życiowego.

Ponieważ motywem działania człowieka szlachetnego jest piękno, więc to go odróżnia w zasadniczy sposób od człowieka dobrego. Człowiek szlachetny ceni ponadto cnoty etyczne dla nich samych, gdyż wie, że postępowanie zgodne z nimi konstytuuje eudaimonię. Jak podkreśla Arystoteles, „piękne są nie tylko cnoty, lecz również czyny, których źródłem jest cnota” (EE, 1248b36-37). Rzecz jasna również człowiek szlachetny pozyskuje

ma właściwą dla siebie cnotę (ảp€tท́); iii) ostateczna, ponieważ jest spełniona, czyli zrealizowała właściwy dla siebie cel (Met, 1021b16-25). Sądzę, że té $\lambda \epsilon$ los w formule

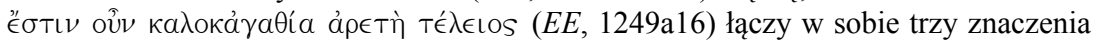
wyróżnione w Metafizyce. Taka interpretacja harmonizuje z charakterystyką prymarnego przyjaciela, przedstawioną w drugim rozdziale siódmej księgi $E E$, a w szczególności z miejscem, w którym Arystoteles sugeruje, że człowiek najwyższej próby jest spełniony

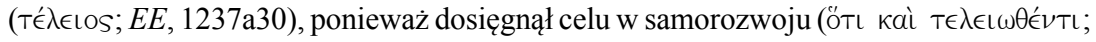
1237a29).

19 Arystoteles mówi o takiej harmonii na przykład w EE, 1240b11-17, ale pełny jej wyraz daje w EN, 1166a13-14: ,taki człowiek [czyli człowiek najwyższej próby - M.S.] zgadza się sam ze sobą, tzn. dąży do tych samych rzeczy całą duszą (öutôs yà ó $\mu_{0-}$

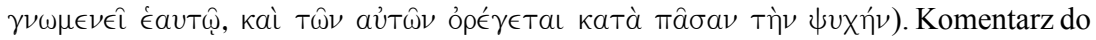
wyróżnionej frazy przedstawiam w Przyjaźń w świetle etyki Arystotelesa (Smolak, 2013, s. 253-260). 
dobra naturalne, ale czyni tak nie dlatego, że uważa je za warte wyboru dla nich samych, lecz dlatego, że posiadanie takich dóbr ułatwia dokonywanie pięknych działań ${ }^{20}$. W efekcie, człowiek szlachetny potrafi sformułować odpowiedź na pytanie ,czym jest eudaimonia i co ją konstytuuje?”. Można więc przyjąć, że w jego przypadku jest spełniona nie tylko teza o nierozdzielności cnót etycznych, lecz również teza o nierozdzielności cnoty etycznej i roztropności. W istocie człowiek szlachetny jest całkowicie dobry pod względem duchowym i dlatego jest właściwym kandydatem do utworzenia przyjaźni prymarnej, a więc tej formy przyjaźni etycznej, której powodem jest nie tyle ta czy inna cnota etyczna, lecz przede wszystkim doskonałość

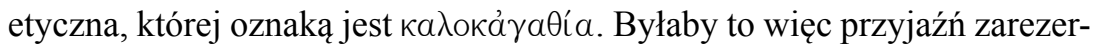
wowana dla ludzi najlepszych, czyli intelektualnych i charakterologicznych herosów (Cooper, 1977, s. 624) - intelektualnych, ponieważ roztropnych, charakterologicznych, ponieważ szlachetnych.

\section{Fragment EE, 1237b4-7}

We fragmencie $E E, 1237 \mathrm{~b} 4-7$ Arystoteles stwierdza:

W konsekwencji, jeśli [przyjaciel] nie będzie sprawiał radości [przyjacielowi] jako dobry, to nie ma prymarnej przyjaźni. Ani żadna z przypadkowych rzeczy nie powinna przeszkodzić do tego stopnia, żeby uniemożliwiła cieszenie się dobrem. Jak to? [Przyjaciel, który] bardzo cuchnie, zostaje opuszczony? Zadowala się bowiem życzliwością i nie przebywa w towarzystwie przyjaciela ${ }^{21}(E E, 1237 \mathrm{~b} 4-7)$.

${ }^{20} \mathrm{~W}$ istocie Arystoteles podkreśla, że dobra naturalne są dlatego piękne dla człowieka szlachetnego, gdyż przy ich pomocy urzeczywistnił wiele pięknych działań (EE, 1249a13-14).

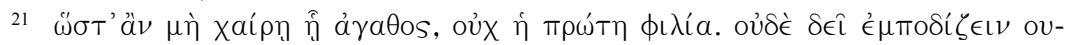

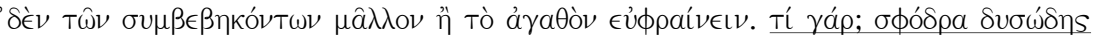

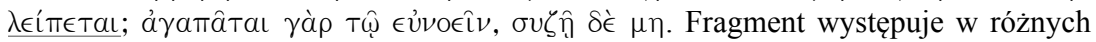
wersjach, co komplikuje jego przekład. Zwracam jednak uwagę przede wszystkim na zapis jego podkreślonej części, ponieważ to ona moim zdaniem decyduje w głównej mierze o eliptyczności całej wypowiedzi. Sądzę bowiem, że Arystoteles stawia podwójne pytanie, a odpowiedź na nie uzależnia i) od okoliczności, w jakich przytrafia się przykry akcydens; ii) od konstytucji samych przyjaciół. Dla porządku podaję kilka

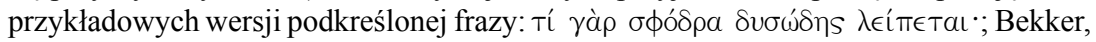
(Aristoteles, 1960) - Bekker proponuje też wprowadzenie emendacji i zastąpienie Tí 
Ponieważ powodem przyjaźni prymarnej jest doskonałe ukonstytuowanie duchowe przyjaciela, więc wydaje się, że jeśli aktywnemu lubieniu nie towarzyszy przyjemność, której jest ono źródłem, to o przyjaźni prymarnej mowy być nie może. W przytoczonym fragmencie Arystoteles zwraca jednak uwagę na sytuację, w której przyczyną niezachodzenia takiej przyjemności może być przykry akcydens przytrafiający się przyjacielowi, a który jest na tyle uciążliwy, że uniemożliwia cieszenie się jego doskonałością duchową. Gdy więc do takiego zdarzenia dochodzi, przyjaciel, którego dotknął ów przykry akcydens, zostaje opuszczony i pozostaje mu jedynie zadowolić się życzliwością tego, który go opuścił22. Ale, jak Arystoteles podkreśla w siódmym rozdziale siódmej księgi $E E$, „ten, kto jest życzliwy, jedynie chce, natomiast jeśli jest przyjacielem, to również czyni to, co chce" (1241a10-12). Ponieważ dotknięty przykrym akcydensem zostaje opuszczony i ma zadowolić się jedynie życzliwością, więc można przyjąć, że opuszczający nie będzie czynił tego, co chce i pozostawi swojego dotychczasowego przyjaciela samego z jego biedą. To by jednak mogło oznaczać, że dotychczasowa przyjaźń mogła być jedynie przyjaźnią pozorną, a jej słabość obnaża rzecz przypadkowa.

Takie odczytanie fragmentu wydaje się niespójne z charakterystyką prymarnego przyjaciela i prymarnej przyjaźni ${ }^{23}$. Proponuję więc spojrzeć na fragment w sposób łagodzący jego niepożądany wydźwięk. Dla potrzeb wywodu zakładam, że inspiracją do takiej wypowiedzi Arystotelesa było zdarzenie, które spotkało Filokteta w drodze na wojnę trojańską. Co prawda osobnikiem, który bardzo cuchnie i który zostaje opuszczony, może być kto-

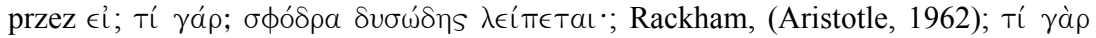
$\sigma \phi o ́ \delta \rho a ~ \delta v \sigma \omega ́ \delta \eta s ~ \lambda \in i ́ \pi \epsilon T a l ; ; ~ Z a n a t t a$, (Aristotele, 2012).

22 W komentarzu do EE Dirlmeier (Aristoteles, 1962, s. 399-400) sugeruje, że w $1237 \mathrm{~b} 7$ mowa jest o zadawalaniu się życzliwością nie przez przyjaciela, który został opuszczony, lecz przez przyjaciela, który opuścił. Dirlmeier stwierdza bowiem: „Żywiona do niego [tzn. do opuszczonego przyjaciela-M.S.] sympatia nie kończy się przez to [tzn. przez przykry akcydens, który przytrafił się opuszczonemu przyjacielowi - M.S.], lecz zmienia się w sympatię na odległość, którą Arystoteles określa jako €ủvola " (s. 399).

23 Zdaniem Galewicza (2002, s. 225) Arystoteles nie stoi na radykalnym stanowisku, że żadna nieistotna przykrość nie może - w żadnym wypadku - doprowadzić do zniszczenia przyjaźni prawdziwych przyjaciół. Bywa bowiem, że nawet w prawdziwej przyjaźni, z czysto akcydentalnych względów, przyjaciel opuszcza przyjaciela, ponieważ przebywanie w jego towarzystwie staje się nie do zniesienia. I nie powinno nas to dziwić, „bo taki już jest ten świat [...] i przyjaźń j e s t wywrotna”. 
kolwiek, ale jak zauważa Galewicz (2002, s. 203-204), istnieją przesłanki, że jest nim nie kto inny, tylko właśnie Filoktet ${ }^{24}$.

\subsection{Nadludzki smród}

Z Filoktetem było tak. Podczas ofiarowywania Apollinowi przez Palamedesa hekatomby w podziękowaniu za zwycięstwo na Tenedos Filokteta ukąsił w nogę wąż, w wyniku czego powstała ropiejąca rana, wydzielająca odrażający zapach. Ponieważ rana nie przestawała cuchnąć, więc towarzysze Filokteta zostawili go na wyspie Lemnos.

Jeśli to zdarzenie ma na myśli Arystoteles, to zachowanie przyjaciół Filokteta daje się usprawiedliwić, ponieważ pod przypadkową rzeczą, która sprawiła, że Filoktet został opuszczony, może kryć się odór niemożliwy do zniesienia przez człowieka, nawet przez przyjaciela etycznego i to bez względu na to, czy jest on dobry, czy szlachetny. Filoktet został bowiem ukarany przez Herę za to, że miał śmiałość rozpalić stos pogrzebowy Heraklesa $^{25}$. Tymczasem zemsta bóstw jest okrutna. Zachodzi zatem prawdopodobieństwo, że smród, jaki wydobywał się z niegojącej się rany Filokteta, był nadludzki. Ale w takim razie wielka bieda Filokteta nie demistyfikuje przyjaźni, lecz ją niszczy. Innymi słowy, przyjaźń Filokteta i jego towarzyszy nie musiała być pozorną przyjaźnią. Towarzysze Filokteta nie porzucili swojego przyjaciela z błahego powodu, lecz na skutek smrodu, którego człowiek ścierpieć nie może.

\subsection{Jednowymiarowe męstwo}

Trzeba podkreślić, że dotychczas opisana historia Filokteta jest niekompletna, ponieważ brakuje w niej ważnych szczegółów - do zdarzenia doszło w trakcie wyprawy Achajów na wojnę trojańską, towarzysze Filokteta prawdopodobnie opiekowali się nim i próbowali go wyleczyć na różne

24 Por. również Reiner, (1991) oraz uwagi poczynione w niniejszym artykule w punkcie 3.3 .

25 Co prawda według przekazów wąż zesłany przez Herę miał pokąsać Filokteta na wyspie Lemnos. Nie zmienia to jednak faktu, że ropiejąca rana mogła być karą bogini za miłosierny uczynek dokonany przez syna Pojasa. Filoktet podpalił bowiem stos pogrzebowy, na który wdrapał się Herakles, w ten sposób skrócił straszliwe męczarnie swojego przyjaciela wywołane przez nasączoną trucizną szatę, podarunek od żony Dejaniry, i przyspieszył jego deifikację. 
możliwe sposoby, ale smród dobywający się z rany nie malał, a jęki Filokteta były coraz bardziej uciążliwe. W rezultacie coraz trudniej było znieść jego udział w wyprawie wojennej. W pewnym sensie jest to zrozumiałe, ponieważ towarzysze Filokteta płynęli, aby wykazać się męstwem, wygrać wojnę i okryć się sławą. Trudno jednak dobrze się przygotować do takiego przedsięwzięcia, jeśli ma się u swojego boku uczestnika wyprawy, który zakłóca spokój i uniemożliwia przygotowanie się do akcji. Dlatego za namową Odyseusza Filoktet został pozostawiony na wyspie Lemnos. Prawdopodobnie Odyseusz, który był znany ze swojej przebiegłości, przekonał wszystkich, że nie ma niczego zdrożnego w porzuceniu przyjaciela w biedzie w takich okolicznościach lub że taki czyn wyjdzie wszystkim na dobre $^{26}$, jednak świadczyłoby to, że przyjaźn Filokteta i jego towarzyszy nie była przyjaźnią prymarną.

$\mathrm{Z}$ tego jednak nie musi wynikać, że była to jedynie przyjaźń utylitarna lub hedoniczna, wszak towarzysze Filokteta, a także on sam, podziwiali się wzajemnie za swoje męstwo i to właśnie było powodem ich wzajemnej fascynacji. W pyle bitewnym byli gotowi poświęcić za przyjaciół nawet własne życie, czemu nie raz dawali świadectwo. Wydaje się jednak, że ich męstwo było jednowymiarowe, ponieważ poza bezpośrednimi działaniami wojennymi nie radzili sobie z własną słabością - towarzysze Filokteta między innymi dlatego, że nie mogli znieść obecności jęczącego i cuchnącego przyjaciela; Filoktet między innymi dlatego, że nie mógł poradzić sobie z własnym cierpieniem. Można więc wysunąć hipotezę, że ich męstwo było podobne do męstwa Lacedemończyków, a ich przyjaźn - do przyjaźni etycznej, ale tej, która była charakterystyczna dla ludzi z mieszaniną dobrych i złych cech charakteru, czyli dobrych w rozumieniu trzeciego rozdziału ósmej księgi EE. Byłaby to więc przyjaźń na miarę tych, którzy ją tworzyli. Zatem i w tym wypadku nie można mówić o demistyfikacji przyjaźni, lecz raczej o jej zniszczeniu. Filoktet, choć był dobry, to jednak na skutek wielkiej biedy, jaka mu się przytrafiła, przestał być dobry dla swoich towarzyszy. Tymczasem, jak podkreśla Arystoteles, ten, kto ma być twoim przyjacielem, powinien być nie tylko dobry, lecz również dobry dla ciebie $(E E, 1238 \mathrm{a} 3-4)$.

26 Na przebiegłość Odyseusza zwraca uwagę Arystoteles w EN, 1146a19-21 odwołując się do Filokteta Sofoklesa. Odyseusz zdawał sobie sprawę, że trudno mu będzie przekonać Neoptolemosa do tego, aby zwiódł Filokteta i wykradł jego łuk, ponieważ mówienie prawdy było dla syna Achillesa czymś pięknym. Aby więc przekonać Neoptolemosa, posłużył się fortelem, kusząc go pozyskaniem podwójnej korzyści za cenę jednorazowego sprzeniewierzenia się samemu sobie (Sofokles, Filoktet, 117-120). 
Gdyby Filoktet i jego towarzysze byli przyjaciółmi prymarnymi, rozpoznaliby w nim człowieka całkowicie dobrego pod względem duchowym, wiedzieliby również, na czym polega prawdziwa przyjaźń i co jest źródłem autentycznej eudaimonii. Zdawaliby więc sobie sprawę, że źródłem przyjemności, dzięki której taka przyjaźń jest odporna na największe przeciwności losu, jest nie tylko konstytucja duchowa przyjaciela, lecz również aktywność realizująca się w warunkach takiej przyjaźni. Gdy Arystoteles stwierdza, że przyjaźń prymarna jest przyjaźnią według cnoty/doskonałości i dla przyjemności, której ona dostarcza (1238a30-31), to wyrażenie „dla przyjemności, której ona dostarcza” oznacza, że chodzi nie tylko o aktywne lubienie stowarzyszone z przyjemnością znajomości z przyjacielem będącym człowiekiem najwyższej próby (1237a30-31), lecz również o przyjemność stowarzyszoną z aktywnościami zgodnymi z cnotami etycznymi. Do takich aktywności należy zaś czynne okazywanie troski przyjacielowi w trybie „ze względu na niego”, dlatego jeśli przyjacielowi w przyjaźni prymarnej przytrafia się przykry akcydens, w postaci na przykład odrażającego smrodu wydzielanego przez ropiejącą ranę, to jego przyjaciel niekoniecznie opuszcza go w niedoli, ponieważ przyjemność przynależna do czynnego okazywania troski prymarnemu przyjacielowi może wyprzeć przykrość przynależną do postrzegania odoru za pomocą zmysłu powonienia.

Takie przypuszczenie nie jest pozbawione podstaw, ponieważ Arystoteles zauważa, że: i) ,przyjemniejsza aktywność wypiera drugą aktywność i to tym bardziej, im bardziej różni się przyjemnością" (EN, 1175b8-9; ii) ,przyjemność odgrywa podobną rolę do przykrości przynależnej do aktywności” (1175b16-17) ${ }^{27}$. W ramach tych dwóch punktów można dodać

27 Arystoteles podejmuje obszerniejsze rozważania na temat przyjemności w dwóch miejscach - w rozdziałach od pierwszego do czternastego siódmej księgi $E N$ ( $=E E$, VI, 11-14; por. przyp. 10) i w rozdziałach od pierwszego do piątego dziesiątej księgi EN. Wśród komentatorów panuje spór, czy wnioski, do jakich Arystoteles dochodzi w obu badaniach są spójne, ponieważ w każdym z nich proponuje inną wykładnię przyjemności. Osobiście uważam, że niespójność jest pozorna, ponieważ pierwsze badanie jest skupione przede wszystkim na przeprowadzeniu polemiki z adwersarzami z punktu widzenia ich teorii, natomiast drugie badanie, obok polemiki z adwersarzami, zawiera ujęcie przyjemności sformułowane niezależnie od krytyki innych stanowisk. Przedstawienie pełnego uzasadnienia tej interpretacji wykracza jednak poza ramy niniejszego artykułu. W tym miejscu zwrócę tylko uwagę, że w drugim rozdziale siódmej księgi $E E$ Arystoteles ma na myśli nie tyle wykładnię przyjemności z siódmej księgi $E N$, w myśl której przyjemność jest nienatrafiającą na przeszkody aktywnością dyspozycji znajdu-

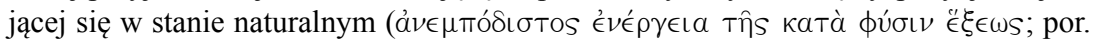


by jeszcze jeden, którego wprawdzie Arystoteles nie formułuje, ale który sformułować by mógł. Otóż w przypadku przyjaciela prymarnego przyjemność przynależna do aktywności najwyższej próby może wyprzeć przykrość przynależną do aktywności niebędącej najwyższej próby i to tym bardziej, im bardziej na pierwszą powinno się decydować, a drugiej powinno się unikać. Poza tym, gdyby na postępowanie prymarnego przyjaciela decydujący wpływ miały doznania zmysłowe, to można by wysunąć niebezpodstawne przypuszczenie, że zachowywałby się analogicznie do akratyka. Tymczasem tam, gdzie jest możliwe wystąpienie akrazji, nie ma jeszcze tego, co jest najwyższej próby $(E E, 1237 \mathrm{a} 7-8)$.

Gdyby więc towarzysze Filokteta pozostawali z nim w związku prymarnej przyjaźni ${ }^{28}$, byliby intelektualnymi oraz charakterologicznymi herosami i nie porzuciliby trudnego do zniesienia przyjaciela przy okazji kolejnego postoju, który wypadł na wyspie Lemnos. Byłaby to bowiem sposobność do okazania troski w trybie ,ze względu na osobę przyjaciela", a także męstwa w pełnym tego słowa znaczeniu zwłaszcza, że to sam Agamemnon wydał Odyseuszowi rozkaz, aby ten pozbył się niewygodnego uczestnika wyprawy.

\subsection{Heroiczna samotność}

W jedenastym rozdziale dziewiątej księgi EN Arystoteles zauważa, że powinniśmy się wahać, czy wezwać przyjaciela w niepowodzeniu, ponieważ w jak najmniejszym stopniu powinniśmy się dzielić z nim złymi rzeczami (1171a16-17). W takim razie otwiera się jednak możliwość jeszcze innego odczytania kontrowersyjnej wypowiedzi, ponieważ to sam Filoktet mógł domagać się od swoich towarzyszy, aby porzucili go na najbliższej wyspie.

1153a14-15), lecz raczej wykładnię przyjemności z dziesiątej księgi $E N$, według której

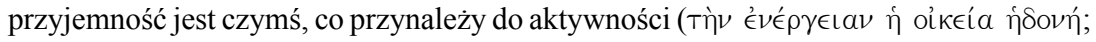
por. np. 1175a30-31). Dość wspomnieć o fragmencie 1236b34-39, czy 1237a22-26. Sądzę więc, że odwoływanie się do ustaleń poczynionych przez Arystotelesa na temat przyjemności w dziesiątej księdze $E N$ jest uzasadnione.

28 Należy zaznaczyć, że zgodnie z tym, na co Arystoteles wielokrotnie zwraca uwagę, Filoktet nie mógł mieć wielu przyjaciół, ponieważ nie można równocześnie aktywnie lubić wielu $(E E, 1238 a 9-10)$. Nie zmienia to jednak faktu, że historia Filokteta świadczy o tym, że nikt $\mathrm{z}$ jego najbliższych towarzyszy nie był przyjacielem prymarnym. 
W EE, $1237 b 7$ Arystoteles używa czasownika $\lambda \in i ́ \pi \omega$, czyli tego samego, jakiego Sofokles używa w dramacie Filoktet w wierszu 1177. Wprawdzie kontekst, w jakim czasownik się pojawia, jest inny, ponieważ nie chodzi o wydarzenie związane z opuszczeniem Filokteta przez przyjaciół na skutek jego smrodu i jęków, lecz o wydarzenie, które miało miejsce dziesięć lat później, gdy Odyseusz wraz Neoptolemosem przybyli na wyspę, aby wykraść łuk Filokteta, potrzebny Achajom do zdobycia Troi. Ale ważne jest to, że we wskazanym wierszu dramatu Sofoklesa, to Filoktet domaga się, aby go zostawić w spokoju. Gdy Chór żeglarzy namawia go, żeby ruszył wraz z nimi na okręt, ten oburza się, że chcą go zabrać do znienawidzonej Troi i zwraca się do nich ze słowami: ,więc mnie już zostawcie i odejdźcie”

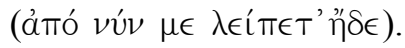

Dla porządku należy dodać, że kilka wierszy wcześniej Filoktet również posługuje się czasownikiem $\lambda \epsilon i$ m $\omega$, ale jego wypowiedź świadczy nie o tym, że chce pozostać sam, lecz raczej o tym, że obawia się, że przybyli żeglarze

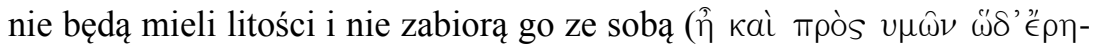

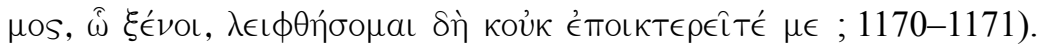

Być może Arystoteles świadomie wykorzystuje czasownik $\lambda \in i$ $\pi \omega$, czyli ten sam, jakiego Sofokles używa w różnych kontekstach w Filoktecie, ponieważ zależy mu na tym, aby jego wypowiedź była eliptyczna i otwarta na różne interpretacje. Filoktet mógł więc spełniać wymogi nałożone na przyjaciela prymarnego i w tak ciężkiej dla niego chwili potrafił zdobyć się na mężną decyzję, wymuszając na swoich towarzyszach, aby pozostawili go samego na wyspie Lemnos. Mógł bowiem zdawać sobie sprawę, że żaden z jego towarzyszy nie wyleczy rany zesłanej przez boginię ${ }^{29}$, zaś jego obecność nie tylko będzie dla nich bolesna, lecz również utrudni dalszą wyprawę pod Troję. I nie byłoby w tym niczego dziwnego, skoro prawdziwy przyjaciel powinien raczej odsunąć się w cień, niż być dla przyjaciela ciężarem nie do zniesienia zwłaszcza, że w przypadku przyjaźni prymarnej przyjaciel jest

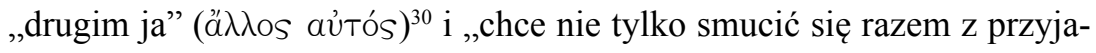

29 Dopiero Machaon, syn nie byle kogo, bo Asklepiosa, boga sztuki lekarskiej spłodzonego przez Apollina i nimfę Kronis, wyleczył Filokteta.

30 Wprawdzie Pakaluk (Aristotle, 1998, s. 173) sugeruje, że określenie ,przyjaciel jest drugim ja" znajduje zastosowanie do przyjaciół tworzących różne typy przyjaźni, jednak Pangle (2003, przyp. 417, s. 272), podkreśla, że byłby to argument na to, że życzliwość ( $€ U ̉ v o l \alpha)$ jest charakterystyką każdej przyjaźni. Tymczasem tak nie jest, czemu Arystoteles daje jednoznaczny wyraz na przykład w siódmym rozdziale siódmej księ- 
cielem, lecz chce także doświadczać tej samej przykrości (...), gdyby to było możliwe" (EE, 1240a36-38). Ponadto, na co zwraca uwagę Pakaluk (2005, s. 285), komentując argument ,ze współpostrzegania” zamieszczony w EN, 1170a13-1170b19, w przypadku przyjaciół najwyższej próby dochodzi do pełniejszej aktualizacji życia. Jest tak dlatego, że przyjaciele nie tylko spostrzegają siebie samych, lecz również spostrzegają, że przyjaciel spostrzega siebie samego. Zatem, mimo że każdy z nich aktualizuje inną możność, to jednak ich duchowa jedność przyczynia się do tego, że wzajemnie partycypują w ich aktualizowaniu. W tej konkretnej sytuacji pełniejsza aktualizacja cierpiącego przyjaciela realizowałaby się jednak na skutek jego uczestnictwa w spostrzeganiu, które byłoby stowarzyszone z podwójną - jeśli tak można powiedzieć - przykrością, cierpiący przyjaciel byłby bowiem świadomy nie tylko własnego cierpienia, lecz również cierpienia swojego przyjaciela, spowodowanego przeżywaniem jego cierpienia - więc że Filoktet sam cierpi, to dość ( $E N, 1171 b 18)$. Jeśli Filoktet był prymarnym przyjacielem, to z racji swojego stanu i okoliczności, w jakich się znalazł, mógł zdobyć się zatem na heroiczną samotność - heroiczną, ponieważ człowiek jest istotą obywatelską i z natury jest przysposobiony do życia z innymi (EN, 1169b18-19). Ale czy musi z tego wynikać, że wielka bieda Filokteta zniszczyła prymarną przyjaźń, przy założeniu, że jego towarzysze (lub któryś z nich) byli na miarę prymarnego przyjaciela? Niekoniecznie, ponieważ znajdowanie się w różnych miejscach nie niweczy przyjaźni całkowicie, lecz niweczy jej aktywność (EN, 1157b10-11). Naturalnie Filoktet przestał przebywać $\mathrm{w}$ towarzystwie przyjaciół i przestał cieszyć się z ich obecności, ale substytutem owego braku mogła być świadomość ich życzliwości. Mógł też żyć nadzieją, że przyjdzie czas, kiedy znów będzie mógł być aktywnym uczestnikiem przyjaźni.

\section{Zakończenie}

Na podstawie przeprowadzonych rozważań można dojść do wniosku, że przyjaźń etyczna, czy to ludzi dobrych, czy też ludzi szlachetnych, nie jest bynajmniej przyjaźnią pozorną. Przedstawione interpretacje łagodzą

gi EE. Kwestią życzliwości, jako warunku i cechy przyjaźni, zajmuję się szczegółowo w Przyjaźń w świetle etyki Arystotelesa (Smolak, s. 206-229). 
kontrowersyjną wypowiedź, w której Arystoteles sugeruje, że przyjaciel, któremu przytrafia się przykry akcydens w postaci smrodu wydzielanego przez jego ciało, pozostaje sam ze swoją biedą.

Ogólnie rzecz ujmując, na gruncie przyjaźni etycznej ludzi dobrych, przyjaciel dotknięty przykrym akcydensem spotyka się prawdopodobnie z troskliwą opieką ze strony przyjaciela. Ale skoro „natura zdaje się unikać przede wszystkim tego, co przykre, a dążyć do tego, co przyjemne" (EN, 1157b16-17) i skoro w przypadku przyjaźni ludzi dobrych przyjemność przynależna do czynnego okazywania troski nie wypiera przykrości stowarzyszonej przykładowo z postrzeganiem silnego odoru, więc opuszczenie przyjaciela i destrukcja przyjaźni są tylko kwestią czasu.

Z kolei w przypadku przyjaźni etycznej ludzi szlachetnych rzecz wydaje się przedstawiać nieco inaczej, jeśli bowiem któregoś z przyjaciół spotyka przykry akcydens, to przyjaciele mogą trwać przy sobie, ponieważ ich wzajemna obecność i aktywność są nośnikami przyjemności, która wypiera przykrość związaną z doświadczaną biedą. A jeśli nawet dochodzi do ich rozłąki, ich przyjaźń nie niszczeje. Pomimo braku przyjemności przynależnej do aktywnego okazywania oznak przyjaźni, pozostaje im przyjemność stowarzyszona $\mathrm{z}$ aktami przypominania i antycypowania. Tymczasem dla człowieka najwyższej próby „wspomnienia dokonanych uczynków są przyjemne i nadzieje na przyszłe dokonania są dobre, a takie nadzieje są przyjemne" (EN, 1166a24-26).

\section{Literatura}

Aristote (1959), L'Éthique ŕ Nicomaque, Tome II: Commentaire par R.A. Gauthier et J.Y. Jolif J.Y., partie 1 et 2, Louvain: Publications Universitaires.

Aristotele (2012), Etica Eudemea, Introduzione, traduzione e note di Marcello Zanatta, Milano.

Aristoteles (1960), Aristotelis Opera, ex recognition I. Bekkeri, edition altera quam curavit O. Gigon, Berolini.

Aristoteles (1962), Eudemische Ethik, übersetzt von F. Dirlmeier, Berlin: Akademie-Verlag.

Aristotle (1954), Ethica Eudemia, transl. J. Solomon, London: Oxford University Press. 
Aristotle (1962), The Eudemian Ethics, transl. H. Rackham, London: The Loeb Classical Library.

Aristotle (1996), Eudemian Ethics, Books I, II, and VIII, Transl. with a Commentary by M. Woods, Oxford: Clarendon Press.

Aristotle (1988), Nicomachean Ethics, Books VIII and IX, Transl. with a Commentary by M. Pakaluk, Oxford: Clarendon Press.

Arystoteles (1977), Etyka Eudemejska, thum. W. Wróblewski, Warszawa: PWN.

Bostock D. (2000), Aristotle's Ethics, New York: Oxford University Press.

Broadie S. (1991), Ethics with Aristotle, New York: Oxford University Press.

Cooper J.M.C. (1977), Aristotle on the Forms of Friendship, Review of Metaphysics, vol. 30.

Engberg-Pedersen T. (1983), Aristotle's Theory of Moral Insight, Oxford: Clarendon Press.

Festugière A.J. (1946), Aristote. Le plaisir (Eth. Nic. VII 11-14, X 1-5), Introduction, traduction et notes, Paris.

Fortenbaugh W.W. (1991), Aristotle's Distinction between Moral Virtue and Practical Wisdom, in J.P. Anton and A. Preus (eds.), Essays in Ancient Greek Philosophy, iv: Aristotle's Ethics, New York: Albany State University of New York Press.

Galewicz W. (2002), Z Arystotelesem przez greckie tragedie, Cz. 1, Glosy i ilustracje do „Etyki nikomachejskiej”, Kraków: Wydawnictwo Literackie.

Irwin T.H. (1990), Aristotle's First Principles, Oxford: Clarendon Press.

Jaeger W. (2001), Paideia, tłum. M. Plezia i H. Bednarek, Warszawa: Fundacja Aletheia.

Kenny A. (1978), The Aristotelian Ethics, Oxford: Clarendon Press.

Pakaluk M. (2005), Aristotle's Nicomachean Ethics, Cambridge: Cambridge University Press.

Pangle L.S., (2003), Aristotle and the Philosophy of Frienship, Cambridge: Cambridge Univeristy Press.

Reiner P. (1991), Aristotle on Personality and Some Implications for Friendship, Ancient Philosophy, vol 11.

Smolak M. (2013), Przyjaźń w świetle etyki Arystotelesa, Kraków: Wydawnictwo Uniwersytetu Jagiellońskiego. 
Sofokles (2009), Filoktet, [w:] Sofokles, Tragedie, t. I, thum. R.R. Chodkowski, Lublin: Towarzystwo Naukowe KUL i Katolicki Uniwersytet Lubelski Jana Pawła II.

Stern-Gillet, S. (1995), Aristotle's Philosophy of Friendship, Alabany (NY).

Vlastos G. (1973), The Individual as Object of Love in Plato, in Platonic Studies, Princeton: Princeton University Press.

\section{IS NOT THE ETHICAL FRIENDSHIP THE APPARENT FRIENDSHIP? - INTERPRETATIONS OF THE EUDEMIAN ETHICS 1237B6-7}

\section{Summary}

In The Eudemian Ethics 1237b6-7 Aristotle seems to suggest that if the ethical friend has an unpleasant odour, he is left by his friend. The article is devoted to demonstrating that the ethical friendship is not the apparent friendship. For this purpose author presents the characteristics of the true friend and distinguishes two types of the ethical friendship, the first between good men, i.e. men with a typical mixture of good and bad traits of character, the second between noble men, i.e. the best men who are heroes of intellect and character - intellect because prudent, character because noble.

On this basis author shows three interpretations which neutralize controversial statement. According to the first interpretation - called "superhuman stink" - unpleasant odour is impossible to endure for the men, even good or noble. Therefore ethical friend must leave his friend in such circumstances. According to the second interpretation - called "one-dimensional courage" - ethical friend, who has an unpleasant odour is left by ethical friend, since one, who leaves can not endure stinking friend. The reason is that he has one-dimensional courage and apart from direct hostilities he does not cope with own weakness. According to the third interpretation - called "heroic solitude" - ethical friend, who has an unpleasant odour does not want to grieve his friend. Therefore decides to heroic solitude - heroic, since a human being is a civic being and one whose nature is to live with others - and leaves his friend. 